\title{
АЛЬТЕРНАТИВНІ СПОСОБИ ЗАХИСТУ ПРАВ СПОЖИВАЧІВ У ЕВРОПЕЙСЬКОМУ СОЮЗІ
}

\begin{abstract}
МАЛИХІНА Яна Анатолї̈вна - доктор педагогічних наук, кандидат юридичних наук, доцент, завідувач кафедри «Правове забезечення та адміністрування транспортної діяльності» Українського державного університету залізничного транспорту

Д'ЯЧКОВА Наталія Анатоліївна - кандидат юридичних наук, доцент, доцент кафедри «Правове забезпечення та адміністрування транспортної діяльності» Українського державного університету залізничного транспорту

ПРОТОПОПОВА Яна Сергіївна - кандидат юридичних наук, доцент кафедри «Правове забезпечення та адміністрування транспортної діяльності» Українського державного університету залізничного транспорту

DOI 10.32782/LAW.UA.2021.3.23
\end{abstract}

У статті, спираючись на аналіз наукових поглядів вчених та норм чинного європейсъкого законодавства, розглянуто особливості досудового захисту прав споживачів у країнах Европейсъкого Союзу.

Здійснено історико-правовий аналіз розвитку консюмеризму в Европейсъкому Союзі. Проаналізовано основні рівні, компоненти та елементи структури позасудової системи захисту прав споживачів на наддержавному та національному рівні краӥн-членів Европейсъкого Союзу. Досліджено систему альтернативних методів вирішення спорів як в окремих європейсъких краӥнах, так і на міждержавному рівні.

Розглянуто основні директиви Европейсъкого Союзу, які регулюють позасудові способи захисту прав споживачів, наведені приклади правозастосовчої практики як Европейсъкого Суду, так і украӥнсъких судів. Висвітлено переваги альтернативних методів вирішення спорів, такі як відносно низъкий рівень затрат у порівнянні з процедурою судового розгляду, конфіденційний характер медіаційних процедур та бажання учасників спору (конфлікту) самостійно врегулювати спір.

Шляхом аналізу веб-сайтів європейських інститутів споживчої політики та аналітичних матеріалів ббахівців у сбері захисту прав споживачів встановлено, що на съогодні питання системного підходу щодо медіаційних (досудових) способів захисту прав споживачів як складової політики нашої держави залишаеться недостатнъо опрацьованим.
Підкреслено, щзо чіткої системи альтернативних способів вирішення спорів щодо захисту прав споживачів у нашій країні на съогодні, на жаль, практично немає. Обгрунтована необхідність вдосконалення чинного законодавства України у конкретних напрямах розвитку позасудових способів вирішення споживацьких спорів відповідно до європейсъких вимог, що допоможе, у тому иислі, повернути довіру громадян до альтернативних способів врегулювання спорів $і$ вплине на зменшення навантаження на суди. Зроблено висновок, що украйнсъке законодавство у иій суері потребує нагального доопрацювання. Запропоновано зміни до норм чинного законодавства з метою його вдосконалення, гармонізачиї та приведення у відповідність до міжнародних стандартів у сфері захисту прав споживачів.

Ключові слова: захист прав споживачів, консюмеризм, медіація, споживач, альтернативні способи вирішення спорів.

\section{Постановка проблеми}

Уклавши угоду про асоціацію з Європейським Союзом, наша країна взяла на себе зобов'язання забезпечити високий рівень захисту прав споживачів (надалі - ЗПС) та досягнути сумісність української системи ЗПС з аналогічними системами держав-членів 6С. 3 огляду на сучасний стан справ у сфері ЗПС вирішення цього питання є серйозним викликом до всіх учасників процесу. 
На сьогодні є розуміння, що Україна має відійти від надмірної зарегульованості бізнесу та одночасно удосконалити механізми його відповідальності перед споживачами. Виробники та продавці повинні усвідомлювати власну відповідальність та прийняти визначальну роль споживачів у бізнес-процесах. Водночас споживачі мають відповідально ставитися до задекларованої презумпції своєї правоти у спорах та пам'ятати, що захист їх прав - це, насамперед, їх вибір та рішення, а вже потім обов'язок контролюючих органів. Тому питання законодавчого врегулювання та вирішення питань ЗПС у країнах Европейського Союзу викликають чималий інтерес і можуть бути прикладом для покращення стану справ у нашій країні.

\section{Аналіз останніх досліджень і публікацій}

Дослідженню європейської системи захисту прав споживачів присвячено праці таких українських вчених, як А. Аазарева [1], С. Дубенко [2], О. Письменна [3], Лащак В.В., Аащак Т.В. [4], Н. Притульська [5] та ін. Роботи вказаних науковців складають теоретичний базис сучасних досліджень, проте, незважаючи на це, багато науковотеоретичних питань цієї теми потребують подальшого дослідження. У наявних наукових доробках, роботах висвітлено загальні засади та елементи споживчої політики у сфері ЗПС на рівні ЕС та України, однак на сьогодні питання системного підходу щодо медіаційних (досудових) способів захисту прав споживачів як складової політики нашої держави залишається недостатньо опрацьованим.

Визначення структури цієї системи дасть змогу заповнити певні прогалини в існуючих наукових дослідженнях та сформувати «еталон», який надалі може використовуватись як наукове підгрунтя для об'єктивної оцінки ефективності існуючої української системи ЗПС, розробки рекомендацій щодо створення в цій сфері нової (сумісної з європейською) системи тощо.

Метою статті є дослідження структури європейської позасудової системи ЗПС на наддержавному та національному рівні кра- їн-членів EС. Методологічну основу статті склали: системний метод - для дослідження структури європейської системи позасудового захисту прав споживачів на наддержавному та національному рівні країн-членів EC, методи аналізу та синтезу - для розкладання цієї системи на складові частини та встановлення зв'язків між ними. Інформаційною базою дослідження є європейське законодавство, веб-сайти європейських інститутів споживчої політики та аналітичні матеріали фахівців у сфері ЗПС.

\section{Результати дослідження}

Історія захисту прав споживачів у Европейському Союзі починається ще з минулого сторіччя. Так, ще у 1912p. у Франції відбулося об'єднання споживчих і кооперативних спілок у Національну федерацію споживчих кооперативів і було прийнято перший консюмерський закон “Про фальсифікацію та підробки у сфері товарів та послуг”. Нiмецькі суди ще у 50-х рр. ХХ ст. почали визнавати недійсними несправедливі умови як споживчих договорів, так і договорів між комерсантами. Як наслідок, у 1976р. цю судову практику було консолідовано у Законі ФРН «Про загальні умови угод». Згідно з 9 цього Закону загальні умови ведення бізнесу 6 недійсними і не підлягають захисту в суді, якщо всупереч принципу добросовісності вони ущемляють права сторони, яка приєдналася до договору. Тобто, якщо умови договору було розроблено однією стороною (підприємцем) заздалегідь і друга сторона (споживач) в силу цього не могла вплинути на їх зміст, то такі умови завжди мають розглядатися як індивідуально невизначені. Згодом аналогічні норми було імплементовано до законодавства інших країн Европи, а віднедавна подібний досвід перейняли й українські суди [6].

Слід відзначити, що на початку утворення EC у Римському Договорі про заснування Европейського економічного співтовариства споживча політика не розглядалась як самостійна мета європейської співпраці. У той час основною метою створення союзу було виключно усунення перешкод в торгівлі між державами-членами, а права фізичних осіб-споживачів залишались поза ува- 


\section{Цивільне, підприємницьке, господарське та трудове право}

гою. Однак з часом Франція, Німеччина та низка інших країн прийняли окремі закони про захист прав споживачів, що започаткувало тенденцію змін на краще у цій сфері по всій Европі.

Цікава ситуація виникла під час прийняття до EС Данії та Великобританії, які ще до вступу прийняли більш прогресивні закони в цій сфері, ніж в інших країнах $\mathrm{EC}$, і під час вступу поставили питання про усунення дискримінації між громадянами їхніх держав та громадянами інших країн-членів EC. Таким чином, кандидати на вступ вимагали підняття рівня захисту споживачів у всіх країнах Європейського Союзу через більшу захищеність власного населення. Така вимога зумовила необхідність вироблення спільної політики EC у цій сфері. Тому на Паризькому саміті 1972р. перед Комісією EC було поставлено завдання розробити спеціальну сферу політики Европейського Союзу, яку потім назвали політикою захисту прав споживачів. Тим самим керівництво EC показало, що метою його створення є не тільки інтереси бізнесу, а й повсякденні інтереси пересічних громадян.

Повноцінною частиною політики Співтовариства консюмеризм став після підписання Маастрихтського договору 1992р., на основі якого в Римський Договір була включена спеціальна стаття 129-а, яку назвали «мінімальний характер» [7]. За нею гарантувалася мінімальна гармонізація сфери захисту прав споживачів на рівні EC. 3 часом вимоги такого «мінімального характеру» було посилено і на сьогодні країни-члени $\mathrm{EC} \mathrm{прагнуть} \mathrm{максимально} \mathrm{гармонізувати}$ національні законодавства, одночасно дозволяючи державам-членам залишити або прийняти національні правила у тій чи іншій галузі.

Звичайно, й на сьогодні, зважаючи на різність менталітетів, історій, ступеню розвитку кожної країни, зіткнення інтересів і культур неминуче. Іноді ці зіткнення носять курйозний характер. Цікавим прикладом конфлікту між національною традицією та правилам EC є ситуація навколо так званого німецького Закону про чистоту пива (Reinheitsgebot), прийнятого ще у 1906p. Відповідно до цього закону, до складу пива можуть входити тільки 3 компоненти: вода, солод і хміль, тому німці не могли собі уявити пиво з інших компонентів і вважали, що якщо напій зроблений не у відповідності 3 цим законом, значить, цей напій не може бути пивом. Закон діяв аж до 1980-х років XX сторіччя, допоки до ФРН не почали імпортувати пиво, яке вироблялося за межами Германії, і, відповідно, відрізнялося за складом від звичного німецького. При цьому імпортери і дистриб'ютори імпортованого пива зіткнулися 3 проблемами, адже продавати їх напої, до складу яких, крім солоду та хмілю входили інші складові, під назвою «пиво» заборонялося. Справа дійшла до судових розглядів, і врешті-решт суперечку було вирішено Судом $\mathrm{EC}$, який дозволив називати пивом напої 3 додатковими компонентами. Суд визнав, що німецький Закон про чистоту пива обмежує свободу пересування товарів, а прикривання захистом прав споживачів не може виправдати встановлення на державному рівні переваг для національних виробників [8]. Проте німецькі виробники пива не розгубилися: вони стали вказувати на етикетках, що «пиво вироблено згідно «Reinheitsgebot»», а отже споживач завжди може перевірити, чи є цей напій справжнім німецьким пивом.

Зараз на міжнаціональному рівні сфера захисту прав споживачів в СС перебуває у віданні вищого виконавчого органу - Европейської комісії, відповідальним органом якої $є$ Генеральний директорат Европейської комісії з охорони здоров'я і захисту споживачів, очолюваний європейським Комісаром з захисту прав споживачів. У споживацькій сфері Рада EС складається з 28 національних міністрів, відповідальних за формування та реалізацію споживчих політик, та одного єврокомісара, який не приймає участі у голосуваннях. При цьому статтями 114 та 169 Договору про функціонування СС встановлено, що Рада EC і Европарламент не можуть приймати рішень щодо політики захисту прав споживачів без проведення консультацій та погодження із спеціальною групою Економічного і соціального комітету EESC «Споживачі та навколишнє середовище».

Безпосередня робота зі споживчим ринком $є$ компетенцію національних органів 
iз захисту прав споживачів NCO (National consumer organisations) та трьох агентств, створених у EC 3 метою захисту прав та реалізації споживчої політики на міжнаціональному рівні: 1) виконавчого агентства 3 питань споживачів, здоров'я та харчування CHAFEA; 2) Европейського агентства з безпеки продуктів харчування EFSA; 3) Европейської організації страхових та професійних пенсій ЕIOРА. Важливу роль відіграють і недержавні органи, зокрема, Европейська асоціація 3 координації та представництва споживачів у сфері стандартизації ANEC та Европейська споживча організація.

Aле загалом кожна країна самостійно визначає власну споживацьку політику. У більшості держав EG питаннями захисту прав споживачів займаються державні органи виконавчої влади, як-то: спеціально створені міністерства споживачів (Міністерство у справах споживачів та державного управління Норвегії, Національний департамент у справах політики захисту споживачів Швеції); міністерства, до компетенції яких проблеми захисту прав споживачів належать частково нарівні з іншими питаннями (Федеральне міністерство охорони здоров'я, спорту та захисту споживачів Австрії, Міністерство у справах економіки Бельгії, Міністерство економіки та Міністерство сільського господарства Франції); управління (бюро, комісія, комітет тощо) - державні органи менш представницького рангу, які входять в структуру міністерств або працюють автономно та займаються виключно проблемами споживачів (Національне агентство у справах споживачів Данії, Національна адміністрація у справах споживачів Фінляндіiі); державні органи, до сфери діяльності яких належать проблеми споживачів нарівні з іншими питаннями (Установа 3 питань покращення якості Іспаніï) [4].

Водночас у деяких країнах, наприклад, Німеччині фактично відсутні загальнодержавні контрольні органи у сфері прав споживачів. Загальний нагляд відбувається на федеральному (місцевому) рівні та за галузями (у сфері енергетики, газу, телекомунікацій, поштових та залізничних послуг). Франція і Польща мають більш звичну для України структуру наглядового органу: у
Франції консюмеризм віднесено до функцій генерального директорату 3 питань конкуренції, споживачів та протидії шахрайству [1], а у Польщі - управління захисту конкуренції та прав споживачів. У Швеції на урядовому рівні проблемами споживачів займається Національний департамент у справах політики захисту споживачів, у Бельгії - Управління у справах комерційної політики споживання при Міністерстві у справах економіки. Найбільш захищеними серед скандинавських країн почуваються жителі Норвегії, вона перша утворила у 1953p. установу, що захищає інтереси споживачів - Раду споживачів, у 1955р. в країні був сформований Інститут інформаційного етикетування товарів. Захистом прав норвезьких споживачів опікується Міністерство у справах споживачів та державного управління та Омбудсмен [9, с. 22].

У багатьох країнах EC захист прав споживачів $є$ прерогативою органів місцевого самоврядування (Іспанія, Німеччина та Швеція). у Німеччині визначальну роль відіграють громадські організації споживачів: Федеральний союз споживачів (Verbraucherzentrale Bundesverband), до якого входять 16 земельних союзів споживачів та 25 галузевих організацій. Найбільш відомою 3 них є Stiftung Warentest, яка здійснює незалежні тестування товарів та послуг і доводить їх результати до громадськості. Усі ці громадські організації лобіюють інтереси споживачів при прийнятті законодавчих актів, відстоюють їх права в судах, беруть участь у позасудовому (альтернативному) вирішенні споживчих спорів, розробленні стандартів на товари та послуги, консультують споживачів з актуальних питань, активно співпрацюють з державними органами та добропорядним бізнесом і т.д.

При безпосередньому вирішенні споживацьких спорів досить часто застосовуються спрощені процедури. Зокрема в Італії передбачена можливість звертатись до судів за спрощеною процедурою, якщо сума спору складає до 100 тис. євро. Як правило, така процедура передбачає можливість швидкого розгляду спору протягом одного засідання і у разі визнання факту порушення прав споживачів завжди вирішується питання 


\section{Цивільне, підприсмницьке, господарське та трудове право}

додаткової компенсації, яка 3 надлишком компенсує споживачу витрати часу та ресурсів на відстоювання своїх прав.

Однак слід відзначити, що, як і в Україні, в європейських країнах споживачі неохоче звертаються до судових органів, особливо коли вартість предмету спору є невисокою. Тому в EС запроваджено понад 750 альтернативних методів вирішення спорів (надалі - АМВС), які стосуються порушення прав як споживачів, так і продавців/надавачів послуг/виконавців робіт [10].

Загальний порядок впровадження та функціонування АМВС регламентується Директивою 2013/11/GC від 21.05.2013p. Про альтернативне вирішення спорів [11]. Ця Директива встановлює основні принципи та вимоги до організації АMBC, загальні стандарти, які застосовуються при вирішенні спорів, спеціальний механізм сертифікації та моніторингу органів АМВС і т.д. При цьому кожна держава має право самостійно встановлювати конкретні процедури АМВС, регламентувати їх обов'язковість чи добровільність тощо. Так, у ст. 6 (а) Директиви встановлене загальне правило про те, що особи, які вирішуватимуть споживацькі спори, повинні мати необхідні знання та навички у сфері альтернативного вирішення спорів, а також загальним розумінням духу закону. Ця вимога конкретизована у Німеччині, де арбітрами можуть бути виключно кваліфіковані юристи чи сертифіковані модератори, а у Чехії та Польщі - особи 3 університетською освітою чи магістри права. Загальне правило статті 8 (с) Директиви про безоплатність або мінімальну вартість для споживача змінене у Словаччині, де вартість такої процедури встановлена до 5 євро, та Данії (до 100 датських крон). Строк у 90 днів для вирішення складних спорів, передбачений у ст. 8 (е) Директиви, у Бельгії може бути додатково подовжений лише один раз до 180 днів, а в Португалії - двічі (максимум до 270 днів).

На загальноєвропейському рівні позасудова мережа вирішення споживацьких спорів складається з ICPEN - підгрупи у Европейській Комісії [12]; ANEC - Европейської асоціації координації споживчого представництва у процесах стандартизації; BEUC
- Европейського бюро споживчих спілок [13] та інших альтернативних органів (погоджувальних центрів і т.д.). У кожній країні існують свої позасудові органи вирішення споживацьких спорів, діяльність яких регламентується як загальноєвропейськими нормами, так і законами окремої держави. Наприклад, у Німеччині юрисдикція таких органів у спорах щодо торгівлі автомобілями обмежена однією землею або одним чи декількома муніципалітетами, а медіаційна діяльність у секторі фінансових послуг та у сфері телекомунікацій поширюється на всю країну.

До складу трибуналу АМВС Германії зазвичай входить лише одна особа, найчастіше - кваліфікований професійний адвокат, який має спеціальні знання в конкретній галузі. У залежності від складності спору склад трибуналу може бути збільшений до 3-5 осіб.

За загальним правилом німецька система альтернативного вирішення спорів базується на добровільній участі сторін конфлікту, коли заявник може у будь-який час припинити розгляд справи, не вказуючи на причини, та звернутися до суду. 3 іншого боку, в деяких федеральних землях закони передбачають примусову спробу примирення як попередню необхідну умову подальшого судового розгляду [14].

У Польщі погоджувальні суди у споживчих справах існують з 1991 p. і є неурядовими організаціями. Справи розглядаються арбітражними групами у складі 3 суддів, причому кожна сторона призначає одного суддю (iз внесених до постійного списку). Такі суди можуть приймати рішення у будь-яких справах, що стосуються спору між споживачем і підприємцем, незалежно від суми претензії, але ця погоджувальна процедура є добровільною, необов'язковою та безкоштовною: споживачі оплачують лише вартість послуг експертів та проведення експертизи, причому ці кошти повертаються, якщо суд виносить рішення на користь споживача [14].

У Аатвії передбачено можливість створення на базі державного органу спеціальних комісій з розгляду споживчих спорів, які розглядають спори на суму від 20 до 
14000 євро і фактично є органом з альтернативного (досудового) вирішення споживацьких спорів.

Національна рада Швеції з розгляду споживчих скарг є державним органом, діяльність якого наближена до судової процедури. Основною метою ії діяльності є неупереджений розгляд спорів між споживачами та суб'єктами бізнесу та надання рекомендацій щодо вирішення спорів. I хоча такі рекомендації не є обов'язковими, але, попри це, більшість компаній їх виконують [14].

У зв'язку із поширенням інтернет-торгівлі 21.05.2013p. Європейською комісією було прийнято Регламент 524/2013 Про онлайн вирішення спорів споживачів та про внесення змін до Регламенту 2006/2004 і Директиви 2009/22/EC3. На підставі цього Регламенту було створено спеціальну вебплатформу для вирішення споживацьких спорів, які виникли при укладанні договорів через інтернет (Платформа ODR), про яку на своїх сайтах обов'язково повинні вказувати усі підприємці, які здійснюють свою діяльність в інтернеті [15]. Платформа ODR являє собою окремий багатомовний вебсайт, на якому споживачі можуть в он-лайн режимі вирішити свої суперечки з бізнесом. На сайті вказаний перелік сертифікованих органів, які можуть здійснювати вирішення спору, а його адміністратори передають суперечку на вирішення органу AMBC, обраного сторонами. Протягом 30 днів справа розглядається i, якщо сторони не дійдуть згоди, справа автоматично закривається, причому таке закриття не перешкоджає зверненню сторін до державних органів вирішення спору. Важливим $€$ й те, що зазначений Регламент про он-лайн вирішення спорів може застосовуватися не лише щодо порушення прав споживачів, а й щодо спорів, ініційованих підприємцями проти недобросовісних клієнтів.

\section{Висновки}

Як бачимо, позасудові органи по вирішенню споживацьких спорів у кожній країні мають свій статус, форму та правила функціонування. Подібний доступ до простих, справедливих та економічних способів вирішення суперечок має багато переваг:
AMBC зміцнює довіру споживачів; через менш формальний та зазвичай примирюючий характер процедур дозволяє сторонам підтримувати стосунки навіть після вирішення спору і дозволяє підприємцям оцінити свою діяльність та отримати конкурентні переваги за рахунок економії затрат на судові процедури, а також продемонструвати високі стандарти обслуговування клієнтів; застосування АМВС знижує навантаження на суди і т.д.

Наразі українське законодавство у цій сфері потребує нагального доопрацювання. Доцільним видається поширення досвіду європейських країн щодо створення системи альтернативних способів вирішення спорів за участю споживачів 3 метою гармонізації українського законодавства та приведення його у відповідність до міжнародних стандартів.

\section{Мітература}

1. Лазарева А. Захист споживачів у Франції / А. Аазарева // Споживач. - 1997. № 7. - С. 36-39;

2. Дубенко С. Споживча політика в системі державного управління / С. Дубенко. - Київ: Нац. акад. держ. упр. при Президентові України, 2009. - 249 с.;

3. Письменна О. Політика Европейського Союзу щодо захисту прав споживачів / Письменна О. - Одеса : Фенікс, 2012. - Вип. 46. - С. 132-140;

4. Лащак В. В., Аащак Т. В. Система захисту прав споживачів у провідних країнах світу / Лащак В. В., Аащак Т. В. // Сучасні проблеми економічної теорії. - Наукові записки Національного університету «Острозька академія». Серія «Економіка». -Вип. 25. - 2014. - С. 15 - 18;

5. Притульська Н., Аига А. Система захисту прав споживачів: досвід $6 \mathrm{C} /$ Притульська Н., Аига А. // Вісник КНТЕУ. - 2018. - № 3. - C. 22-36;

6. Рішення Вишгородського районного суду Київської області у справі№ 363/2175/19 (провадження 2/363/1547/19) [Електронний ресурс] // Єдиний державний реєстр судових рішень. - 2019. - Режим доступу до ресурсу: https://reyestr.court.gov.ua/ Review/85753851; 


\section{Цивільне, підприсмницьке, господарське та трудове право}

7. Договір про заснування Европейської Спільноти (Договір про заснування Европейського економічного співтовариства) [Електронний ресурс]. - 2503. - Режим доступу до ресурсу: https://zakon.rada.gov.ua/ laws/show/994_017\#Text;

8. Баварський закон “Про чистоту пива” [Електронний ресурс] - Режим доступу до ресурсу: https://romantikspahotels.ua/ uk/do-pyva/;

9. Захист прав споживачів у Европейському Союзі та Україні: аналіт. звіт / Спільний проект Европейського Союзу та Програми розвитку Організації Об'єднаних Націй; Спільнота споживачів та громадські об'єднання - К., 2007. - 36 с.;

10. Making rights a reality: New Europewide support network for consumers [Електронний ресурс]. - 2004. - Режим доступу до ресурсу: http://ec.europa.eu/consumers/ redress/out_of_court/adr_recommendations en.htm;

11. Директива 2013/11/EU Европейского парламента и Совета от 21 мая 2013 года относительно альтернативного разрешения споров в сфере потребления [Електронний ресурс]. - 2013. - Режим доступу до ресурсу: https://mediation-eurasia.pro/ wp-content/uploads/2018/04/direktiva-201311-eu-evropejskogo-parlamenta-i-soveta-ot-21maja-2013-goda-otnositelno-alternativnogorazreshenija-sporov-v-sfere-potreblenija.pdf;

12. International Consumer Protection and Enforcement Network (ICPEN) [Електронний ресурс] - Режим доступу до ресурсу: https://icpen.org/;

13. Bureau Européen des Unions de Consommateurs [Електронний ресурс] - Peжим доступу до ресурсу: https://www.beuc. $\mathrm{eu} /$;

14. Захист прав споживачів в Европейському Союзі та Україні. Аналітичний звіт. Спільний проект Европейського Союзу та Програми розвитку Організації Об'єднаних Націй [Електронний ресурс]. - 2007. - Режим доступу до ресурсу: http:// www.consumerinfo.org.ua/upload/iblock/377/ ConsumerProtectionReport-ua.pdf;

15. Online Dispute Resolution [Електронний ресурс] - Режим доступу до ре-

\section{SUMMARY}

The article, based on the analysis of scientific views of scientists and the norms of current European legislation, considers the features of pre-trial consumer protection in the European Union.

A historical and legal analysis of the development of consumerism in the European Union. The main levels, components and elements of the structure of the out-of-court system of consumer protection at the supranational and national level of the European Union member states are analyzed. The system of alternative methods of dispute resolution has been studied both in some European countries and at the interstate level.

The main directives of the European Union, which regulate extrajudicial methods of consumer protection, are considered, examples of law enforcement practice of both the European Court and Ukrainian courts are given. The advantages of alternative methods of dispute resolution, such as the relatively low level of costs compared to the court procedure, the confidential nature of mediation procedures and the desire of the parties to the dispute (conflict) to resolve the dispute independently, are highlighted.

By analyzing the websites of European consumer policy institutes and analytical materials of experts in the field of consumer protection, it is established that today the issue of a systematic approach to mediation (pre-trial) methods of consumer protection as part of our state policy remains insufficiently addressed.

It is emphasized that, unfortunately, there is practically no clear system of alternative ways of resolving disputes concerning consumer protection in our country. The need to improve the current legislation of Ukraine in specific areas of out-of-court settlement of consumer disputes in accordance with European requirements, which will help, among other things, restore public confidence in alternative dispute resolution and reduce the burden on the courts. It is concluded that the Ukrainian legislation in this area needs urgent revision. It is proposed to amend the current legislation in order to improve it, harmonize it and bring it in line with international standards in the field of consumer protection.

Key words: consumer protection, consumerism, mediation, consumer, alternative dispute resolution.

cypcy: https:/ec.europa.eu/consumers/odr/ main/?event $=$ main.home2. . show . 